\title{
Color Plates
}

I. Codex Borbonicus 4 xvii

2. Codex Fejérváry-Mayer 33-34 xviii

3. Codex Tudela 98v-99r $x i x$

4. Codex Borgia 7I $x x$

5. Codex Vaticanus B $96 x x$

6. Codex Fejérváry-Mayer I $x x i$

7. Codex Borgia 49 xxii

8. Codex Borgia $27 x x i i$

9. Codex Cospi 9 xxiii

Io. Codex Laud I2 xxiii

II. Codex Borgia $29 x x i$ v

I2. Codex Borgia $30 x x i v$ 
THIS PAGE INTENTIONALLY LEFT BLANK 